19 Revue d'histoire du XIXe siècle

Société d'histoire de la révolution de 1848 et des

révolutions du XIXe siècle

$11 \mid 1995$

L'exil

\title{
L'affaire Dreyfus cent ans après
}

Jean-Yves Mollier

OpenEdition

Journals

Electronic version

URL: http://journals.openedition.org/rh19/84

DOI: $10.4000 /$ rh19.84

ISSN: $1777-5329$

Publisher

La Société de 1848

Printed version

Date of publication: 1 June 1995

ISSN: 1265-1354

Electronic reference

Jean-Yves Mollier, «L'affaire Dreyfus cent ans après », Revue d'histoire du XIXe siècle [Online], 11 | 1995,

Online since 09 September 2008, connection on 03 May 2019. URL : http://journals.openedition.org/ rh19/84 ; DOI : 10.4000/rh19.84

This text was automatically generated on 3 May 2019.

Tous droits réservés 


\section{L'affaire Dreyfus cent ans après}

Jean-Yves Mollier

\section{ABSTRACTS}

No abstract available by now

Pas de résumé disponible actuellement

INDEX

Mots-clés: Exil, Affaire Dreyfus 